\title{
Warfare: Most dangerous threat to the Environment
}

\author{
Bharati Sharma ${ }^{1}$ and Sanjay Tignath ${ }^{2}$ \\ ${ }^{I}$ Professor, Department of Military Science \\ ${ }^{2}$ Professor, Department of Geology \\ Govt. Autonomous Science College, Jabalpur, MP
}

\begin{abstract}
This paper is based on the various reports related to the environmental impacts of war on the Asian countries since the atomic explosion of World War II. After the explosion has caused the physical damage to the object by bombs of high explosive content, the dangerous material is directed to the environment. It is this part of warfare material in the form of chemicals, radiations, heat etc. that hangs around in the environment and damage those who were never a part of the war.
\end{abstract}

Key word; Atomic, damage, explosion, impact

\section{Introduction}

The application of weapons, the destruction of structures and oil fields, fires, military transport movements and chemical spraying are all examples of the destructive impact that a war may have on the environment. Air, water and soil are polluted, man and animal are killed, and numerous health affects occur among those still living. This page is about the environmental effects of wars and incidents leading to war that had occurred in the 20th and 21 st century.

The impacts of war on environment are:

Immediate Destruction: Loss of Life, wealth, peace and System

Long term Destruction

a. Excessive infusion of dangerous contaminants in Environs

b. Epidemics

c. Genetic defects in Post-war generations

\section{Case Studies and Reviews}

The present study presents the reviews of the losses of all possible kinds that a war can throw upon the people of a land. We now know that the environmental impacts are never restricted to the lands of war rather the effects are circulated on the global scale. It is thus jeopardising the whole life just in dealing with a land and a boundary which must be solved amicably.

In Hiroshima a number of small fires combined with wind formed a firestorm, killing those who did not die before but were left immobile for some reason. Within days after the blasts, radiation sickness started rearing its ugly head, and many more people would die from it within the next 5 years.

The total estimated death toll:

In Hiroshima 100,000 were killed instantly, and between 100,000 and 200,000 died eventually. In Nagasaki about 40,000 were killed instantly, and between 70,000 and 150,000 died eventually.

The events of August 6 and August 9-1945 can be translated into environmental effects more literally. The blasts caused air pollution from dust particles and radioactive debris flying around, and from the fires burning everywhere. Many plants and animals were killed in the blast, or died moments to months later from radioactive precipitation. Radioactive sand clogged wells used for drinking water winning, thereby causing a drinking water problem that could not easily be solved. Surface water sources were polluted, particularly by radioactive waste. Agricultural production was damaged; dead stalks of rice could be found up to seven miles from ground zero. In Hiroshima the impact of the bombing was noticeable within a 10 $\mathrm{km}$ radius around the city, and in Nagasaki within a $1 \mathrm{~km}$ radius.

The Gulf War was fought between Iraq, Kuwait and a number of western countries in 1991. Kuwait had been part of Iraq in the past, but was liberated by British imperialism, as the Iraqi government described it. In August 1990, Iraqi forces claimed that the country was illegally extracting oil from Iraqi territory, and attacked. The United Nations attempted to liberate Kuwait. Starting January 1991, Operation Desert Storm began, with the purpose of destroying Iraqi air force and anti-aircraft facilities, and command and control facilities. The battle was fought in Iraq, Kuwait and the Saudi-Arabian border region. Both aerial and ground artillery was applied. Late January, Iraqi aircraft were flown to Iran, and Iraqi forces began to flee.

The Gulf War was one of the most environmentally devastating wars ever fought. Iraq dumped approximately one million tons of crude oil into the Persian Gulf, thereby causing the largest oil spill in history. Approximately 25,000 migratory birds were killed. The impact on marine life was not as severe as expected, because warm water sped up the natural breakdown of oil. Local prawn fisheries did experience problems after the war. Crude oil was also spilled into the desert, forming oil lakes covering 50 square kilometres. In due time the oil percolated into groundwater aquifers. 
Fleeing Iraqi troops ignited Kuwaiti oil sources, releasing half a ton of air pollutants into the atmosphere. Environmental problems caused by the oil fires include smog formation and acid rain. Toxic fumes originating from the burning oil wells compromised human health, and threatened wildlife. A soot layer was deposited on the desert, covering plants, and thereby preventing them from breathing. Seawater was applied to extinguish the oil fires, resulting in increased salinity in areas close to oil wells. It took about nine months to extinguish the fires.

During the war, many dams and sewage water treatment plants were targeted and destroyed. A lack of possibilities for water treatment resulting from the attacks caused sewage to flow directly into the Tigris and Euphrates rivers. Additionally, pollutants seeped from bombed chemical plants into the rivers. Drinking water extracted from the river was polluted, resulting in widespread disease. For example, cases of typhoid fever have increased tenfold since 1991.

Movement of heavy machinery such as tanks through the desert damaged the brittle surface, causing soil erosion. Sand was uncovered that formed gradually moving sand dunes. These dunes may one day cause problems for Kuwait City. Tanks fired Depleted Uranium (DU) missiles, which can puncture heavy artillery structures. DU is a heavy metal that causes kidney damage and is suspected to be teratogenic and carcinogenic. Post-Gulf War reports state an increase in birth defects for children born to veterans. The impact of Depleted Uranium could not be thoroughly investigated after the Gulf War, because Saddam Hussein refused to cooperate. Its true properties were revealed after the Kosovo War in 2001 (description below). DU has now been identified as a neurotoxin, and birth defects and cancers are attributed to other chemical and nerve agents. However, it is stated that DU oxides deposited in the lungs of veterans have not been thoroughly researched yet. It was later found that this may cause kidney and lung infections for highly exposed persons.

After the Gulf War many veterans suffered from a condition now known as the Gulf War Syndrome. The causes of the illness are subject to widespread speculation. Examples of possible causes are exposure to DU (see above), chemical weapons (nerve gas and mustard gas), an anthrax vaccine given to $41 \%$ of US soldiers and $60-75 \%$ of UK soldiers, smoke from burning oil wells and parasites. Symptoms of the GWS included chronic fatigue, muscle problems, diarrhoea, migraine, memory loss, skin problems and shortness of breath. Many Gulf War veterans have died of illnesses such as brain cancer, now acknowledged as potentially connected to service during the war.

Iraq \& the United States - The war in Iraq started by the United States in 2003 as part of the War on Terrorism causes poverty, resulting in environmental problems. Long-term environmental effects of the war remain unclear, but short-term problems have been identified for every environmental compartment. For example, some weapons are applied that may be extremely damaging to the environment, such as white phosphorus ammunition. People around the world protest the application of such armoury.

\section{Water}

Damage to sanitation structures by frequent bombing, and damage to sewage treatment systems by power blackouts cause pollution of the River Tigris. Two hundred blue plastic containers containing uranium were stolen from a nuclear power plant located south of Baghdad. The radioactive content of the barrels was dumped in rivers and the barrels were rinsed out. Poor people applied the containers as storage facility for water, oil and tomatoes, or sold them to others. Milk was transported to other regions in the barrels, making it almost impossible to relocate them.

\section{Air}

Oil trenches are burning, as was the case in the Gulf War of 1991, resulting in air pollution. In Northern Iraq, a sulphur plant burned for one month, contributing to air pollution. As fire continues burning, groundwater applied as a drinking water source may be polluted.

\section{Soil}

Military movements and weapon application result in land degradation. The destruction of military and industrial machinery releases heavy metals and other harmful substances.

Israel \& Lebanon - In July 2006, Hezbollah initiated a rocket attack on Israeli borders. A ground patrol killed and captured Israeli soldiers. This resulted in open war between Israel and Lebanon.

The war caused environmental problems as Israelis bombed a power station south of Beirut. Damaged storage tanks leaked an estimated 20,000 tons of oil into the Mediterranean Sea. The oil spill spread rapidly, covering over $90 \mathrm{~km}$ of the coastline, killing fish and affecting the habitat of the endangered green sea turtle. A sludge layer covers Beaches across Lebanon, and the same problem may occur in Syria as the spill continues to spread. Part of the oil spill burned, causing widespread air pollution. Smog affects the health of people living in the city of Beirut. So far problems limiting the clean-up operation of oil spills have occurred, because of ongoing violence in the region.

Another major problem was forest fires in Northern Israel caused by Hezbollah bombings. A total of 9,000 acres of forest burned to the ground, and fires threaten tree reserves and bird sanctuaries.

Russia \& Chechnya - In 1994 the First Chechen War of independence started, between Russian troops, Chechen guerrilla fighters and civilians. Chechnya has been a province of Russia for a very long time and now desires independence. The First War ended in 1996, but in 1999 Russia again attacked Chechnya for purposes of oil distribution. 
The war between the country and its province continues today. It has devastating effects on the region of Chechnya. An estimated $30 \%$ of Chechen territory is contaminated, and $40 \%$ of the territory does not meet environmental standards for life. Major environmental problems include radioactive waste and radiation, oil leaks into the ground from bombarded plants and refineries, and pollution of soil and surface water. Russia has buried radioactive waste in Chechnya. Radiation at some sites is ten times its normal level. Radiation risks increase as Russia bombs the locations, particularly because after 1999 the severeness of weaponry increased. A major part of agricultural land is polluted to the extent that it can no longer meet food supplies. This was mainly caused by unprofessional mini-refineries of oil poachers in their backyards, not meeting official standards and causing over $50 \%$ of the product to be lost as waste. Groundwater pollution flows into the rivers Sunzha and Terek on a daily basis. On some locations the rivers are totally devoid of fish. Flora and fauna are destroyed by oil leaks and bombings.

Vietnam war - The Vietnam War started in 1945 and ended in 1975. It is now entitled a proxy war, fought during the Cold War between the United States and the Soviet Union to prevent the necessity for the nations to fight each other directly. North Vietnam fought side by side with the Soviet Union and China, and South Vietnam with the United States, New Zealand and South Korea. It must be noted that the United States only started to be actively involved in the battle after 1963. Between 1965 and 1968 North Vietnam was bombed under Operation Rolling Thunder, in order to force the enemy to negotiate. Bombs destroyed over two million acres of land. North Vietnam forces began to strike back, and the Soviet Union delivered anti-aircraft missiles to North Vietnam. The ground war of US troops against the Viet Cong began. The United States would not retreat from Vietnam until 1973, and during those years extremely environmentally damaging weapons and war tactics were applied.

A massive herbicidal programme was carried out, in order to break the forest cover sheltering Viet Cong guerrillas, and deprive Vietnamese peasants of food. The spraying destroyed $14 \%$ of Vietnam's forests, diminished agricultural yield, and made seeds unfit for replanting. If agricultural yield was not damaged by herbicides, it was often lost because military on the ground set fire to haystacks, and soaked land with aviation fuel en burned it. A total of 15,000 square kilometres of land were eventually destroyed. Livestock was often shot, to deprive peasant of their entire food supply. A total of 13,000 livestock were killed during the war.

The application of 72 million litres of chemical spray resulted in the death of many animals, and caused health effects with humans. One chemical that was applied between 1962 and 1971, called Agent Orange, was particularly harmful. Its main constituent is dioxin, which was present in soil, water and vegetation during and after the war. Dioxin is carcinogenic and teratogenic, and has resulted in spontaneous abortions, chloracne, skin and lung cancers, lower intelligence and emotional problems among children. Children fathered by men exposed to Agent Orange during the Vietnam War often have congenital abnormalities. An estimated half a million children were born with dioxin-related abnormalities. Agent Orange continues to threaten the health of the Vietnamese today.

\section{Conclusions}

Young women in Fallujah in Iraq are terrified of having children because of the increasing number of babies born grotesquely deformed, with no heads, two heads, a single eye in their foreheads, scaly bodies or missing limbs. In addition, young children in Fallujah are now experiencing hideous cancers and leukaemia. These deformities are now well documented, for example in television documentaries on SKY UK on September 2009 and on SKY UK June 2008. Our direct contact with doctors in Fallujah report that:

In September 2009, Fallujah General Hospital had 170 new born babies, 24\% of whom were dead within the first seven days, a staggering $75 \%$ of the dead babies were classified as deformed.

Circulation of Winds were seen to show disturbances

Warming up and freezing down were seen to increase in range.

Permanent contamination of water resources and high pollution to air.

Epidemics

Economic rupture

[1]. www.restoring water systems in Iraq

\section{Reference}

[2]. www. environmental disasters

[3]. www. Worldwardisasters 